\title{
Pencegahan Hazard Radiasi pada Ibu Hamil
}

\author{
Lili Evalina
}

lili.evalina@gmail.com

\section{Latar Belakang}

Ibu hamil memang perlu untuk dijaga lebih ekstra karena didalamnya tekandung janin yang masih sangat lemah terhadap berbagai hal yang tidak baik, selain karena janin atau bayi yang masih di dalam kandungan belum bisa menjaga dirinya sendiri karena masih menyatu dengan ibunya, bayi dalam kandungan juga belum memiliki imun yang kuat sehingga mudah terpapar berbagai hal yang dapat menghambat pertumbuhan bayi dalam kandungan itu sendiri. Karena bayi dalam kandungan masih menjadi satu dengan ibunya, maka penting bagi ibu hamil untuk memiliki kesadaran dalam menjaga bayi dalam kandungannya tersebut. Hal ini bisa dilakukan dengan mempelajari dan memahami apa saja yang harus dipenuhi bagi ibu hamil dan bayi dalam kandungan, serta mempelajari dan memahami juga hal - hal yang harus dihindari selama masa kehamilan tersebut.

Salah satu hal yang harus dihindari oleh ibu hamil adalah radiasi. Hal ini karena radiasi sendiri merupakan suatu bentuk energi yang bergerak dalam bentuk sinar maupun partikel di udara, dam dapat melekat layaknya debu dan cairan. Lalu mengapa radiasi menjadi berbahaya bagi ibu hamil? Hal ini karena ibu hamil yang terpapar radiasi dapat menyebabkan berbagai gangguan terhadap janin yang dikandung, seperti keguguran, cacat lahir, kanker dan lain - lain, namun sebagian besar kasus yang terjadi mengarah pada kecacatan. Meski pada dasarnnya pada masa awal dan masa akhir perkembangan bayi dalam kandungan bersifat resistan terhadap radiasi, namun hal ini tidak terjadi pada setiap bayi. Ibu dan bayi yang lemah akan lebih mudah terkena dampak dari pemaparan radiasi ini sehingga penting bagi setiap ibu hamil.

Pengetahuan ibu hamil dalam hal ini juga sangat pentingh karena sangat banyak benda benda yang dapat memaparkan radiasi, meski alat kedokteran sekalipun seperti beberapa alat pada dokter gigi dan CT Scan, serta alat - alat lainnya yang banyak digunakan dalam kehidupan sehari - hari seperti handphone dan mesin $x$-ray yang biasanya digunakan di pintu masuk mall atau bandara dan beberapa tempat umum lainnya untuk memeriksa benda yang dibawa saat akan 
memasuki tempat tersebut. Apabila ibu hamil tidak memiliki pengetahuan akan hal ini, maka ada kemungkinan ibu hamil tidak memiliki kewaspadaan terhadap benda - benda yang berpotensi memancarkan radiasi yang bisa berbahaya bagi pertumbuhan bayi di dalam kandungannya tersebut.

\section{Metode}

Metode yang digunakan dalam penulisan jurnal ini adalah metode kualitatif dengan pendekatan kajian pustaka. Dalam penelitian ini data yang digunakan berasal dari sumber sumber dengan topik yang bersangkutan seperti jurnal - jurnal kedokteran, khususnya yang membahas tentang kehamilan. Dalam arti lain dengan menggunakan kajian pustaka, maka apa yang dituliskan dalam jurnal ini merupakan hasil dari penelitian terdahulu yang sudah disajikan dalam jurnal - jurnal yang digunakan sebagai referensi. Dengan menggunakan metode kualitatif ini juga data yang disampaikan akan berbentuk penulisan dan penjabran dan tidak dipaparkan secara statistik.

\section{Hasil}

Berdasarkan pemaparan yang sudah disampaikan pada abstrak dan latar belakang, maka sudah ada sedikit gambaran mengenai apa itu hazard apa itu radiasi dan apa bahaya dari radiasi bagi ibu hamil dan janinnya. Maka dari itu berdasarkan gambaran secara garis besar yang sudah dipaparkan diatas, maka dari itu perlu juga mengetahui bagaimana pencegahan yang baik terhadap hazard radiasi bagi ibu hamil. Selain karena sangat banyak alat yang dapat memaparkan radiasi yang berbahaya bagi ibu hamil, dampak yang terjadi apabila ibu hamil terpapar radiasi dengan intensitas yang tinggi juga tidak main - main, karena dampak yang dapat terjadi mulai dari penyakit, cacat lahir, hingga yang paling parah adalah keguguran.

Maka dari itu, salah satu upaya yang dapat dilakukan oleh ibu hamil agar terhindar dari hazard radiasi adalah dengan memahami dan mengetahui alat - alat pemapar radiasi itu sendiri sehingga dapat menjauhkan diri dari alat - alat tersebut. Meski tidak semua ibu hamil dan janin rentan terkena radiasi dan mengakibatkan kecacatan, namun untuk berjaga - jaga, ibu hamil harus menjaga dirinya sendiri karena janin tersebut masih menyatu dengan tubuhnya sendiri. 
Hazard sendiri seperti yang juga sudah disampaikan diatas, adalah suatu kerusakan yang pada akhirnya akan mengarah pada kerugian. Dalam kehamilan, kerusakan yang dimaksud adalah kecacatan dan lain - lain atau biasanya disebut dengan birt defect. Radiasi sendiri selain dari pancaran alat - alat, radiasi juga dapat berupa sesuatu yang dapat dikonsumsi, maka apabila ibu menelan sesuatu yang mengandung radiasi, maka radiasi tersebut akan memasuki aliran darah dan menuju ke tali pusar hingga akhirnya mengenai janin. Selain masuk ke dalam aliran darah karena mengkonsumsi sesuatu yang mengandung radiasi, radiasi juga dapat menempel pada tubuh dalam waktu yang lama karena dihantarkan melalui udara.

Selain memahami dan mengetahui alat - alat apa saja yang dapat memancarkan radisi, ibu hamil juga perlu memahami dan memperhatikan apa yang dikonsumsi selama kehamilan. Karena kemabali lagi, janin yang ada dalam kandungan masih menjadi satu dengan ibu itu sendiri sehingga apapun yang terjadi dan dialami oleh ibunya, maka otomatis akan dialami oleh janin itu juga, termasuk salah satunya adalah sesuatu yang dikonsumsi oleh ibunya, maka akan dikonsumsi oleh janin dalam kandungan itu juga.

\section{Pembahasan}

Kerentanan ibu hamil terhadap berbagai hal menjadi suatu hal yang wajar terjadi mengingat kondisi ibu hamil yang dapat dikatakan sedang 'berbadan dua' karena didalamnya terdapat janin yang sedang melalui masa pertumbuhan dalam kandungan ibunya. Maka dari itu seorang ibu hamil perlu memiliki pengetahuan yang tepat terhadap hal - hal yang berkaitan dengan kehamilan dan kesehatan ibu dan bayi dalam kandungannya dengan memahami berbagai hal yang harus dipenuhi dan harus dihindari selama masa kehamilan agar kesehatan ibu dan perkembangan bayi dalam kandungan dapat terjaga.

Hal yang harus dilengkapi oleh seorang ibu hamil tentu seperti vitamin - vitamin pelengkap, nutrisi, dan berbagai aktivitas fisik yang dapat memberikan dampak positif bagi ibu dan bayi dalam kandungan selama masa kehamilan seperti melakukan yoga khusus ibu hamil dan beberapa olahraga lainnya. Namun bukan hanya itu yang perlu diperhatikan oleh ibu hamil, melainkan mengenai beberapa ancaman dari lingkungan sekitar yang dapat menimbulakan hazard yang akan menimbulkan birth defect pada bayi. Beberapa hal yang harus diperhatikan 
oleh ibu hamil selama masa kehamilanya, terutama dalam masa - masa rentan seperti pada awal kehamilan dan beberapa fase kehamilan lainnya.

Yang harus diperhatikan oleh ibu hamil dapat dikatakan berasal dari berbagai aspek, mulai dari makanan yang dikonsumsi, kegiatan yang dilakukan, hingga penggunaan alat - alat tertentu yang memancarkan atau menghasilkan sesuatu yang tidak baik untuk ibu hamil dan perkembangan janin. Makanan yang harus dihindari oleh ibu hamil salah satunya adalah makanan mentah, seperti sashimi yang merupakan daging ikan mentah yang biasanya disajikan di restoran - restoran Jepang dan makanan yang terlalu asam ataupun pedas. Sedangkan kegiatan yang sebaiknya dihindari oleh ibu hamil sebagian besar adalah aktivitas - aktivitas yang berat dan aktivitas yang tidak sehat lainnya seperti mengangkat benda - benda yang berat, begadang, dan lain - lain.

Yang terakhir adalah menghindari alat - alat yang dapat menghasilkan dan memaparkan sesuatu yang tidak baik untuk ibu hamil dan perkembangan janin selama masa kehamilan, seperti salah satunya adalah radiasi. Ibu hamil yang terpapar radiasi dapat mengalami berbagai hazard, seperti kecacatan bayi, penyakit seperti kanker atau potensi terkena kanker, hingga keguguran. Namun hal ini menjadi sulit karena radiasi ini terdapat pada beberapa benda atau alat yang akrab dengan kehidupan sehari - hari, seperti contohnya telepon genggam dan pancaran wi-fi. Telepon gengang dan wi-fi adalah dua hal yang sangat umum dimiliki oleh semua orang di era saat ini, bahkan dalam berbagai lapisan dan golongan.

Ibu hamil yang tidak memiliki pengetahuan yang memadai mengenai apa saja hal yang harus dihindari selama masa kehamilan, memiliki potensi lebih besar untuk mengalami hazard radiasi ini, mengingat fakta bahwa radiasi menjadi sesuatu hal yang sangat mudah ditemui di berbagai alat yang dekat dengan kehidupan sehari - hari kita. Salah satu upaya yang dapat dilakukan oleh ibu hamil agar terhindari dari pancaran radiasi yang berasal dari telepon genggam dan router wi-fi adalah dengan menurunkan intensitas penggunaan telepon genggam itu sendiri, dan tidak sering meletakkan telepon genggam tersebut di sekitaran. Sedangkan untuk router wifi, salah satu upaya yang dapat dilakukan adalah dengan menonaktifkan sementara wi-fi yang ada. Namun apabila wi-fi tersebut diperlukan oleh anggota keluarga lain, maka dapat dipasang dengan jarak yang jauh dari sekitaran tempat ibu hamil sering melakukan aktivitas sehari harinya, seperti di kamar tidur. 
Alat lainnya yang dapat memancarkan dan memaparkan radiasi adalah alat yang digunakan pada pemeriksaan rontgen atau sinar-x. Alat ini juga menjadi alat yang mudah ditemukan, terutama dalam bidang kesehatan seperti di rumah sakit. Maka dari itu, penting bagi ibu hamil untuk setidaknya mengetahui alat - alat kesehatan apa saja yang dapat memancarkan radiasi dan penting juga bagi ibu hamil untuk selalu menginformasikan kepada dokter apabila sedang melakukan pemeriksaan selain pemeriksaan kehamilan mengenai kondisi kehamilan tersebut agar dokter yang bersangkutan dapat memberikan penanganan yang tepat.

Alat selanjutnya yang juga dapat memancarkan radiasi dan lebih mudah lagi untuk ditemui sehari - hari dibandingkan dengan alat kesehatan adalag alat pemeriksaan detector metal yang bisa ditemukan di pintu - pintu masuk beberapa fasilitas umum seperti bandara, mall, hotel, dan lain - lain. Kembali lagi kepada apabila ibu hamil tersebut tidak paham bahwa alat pemerikasaan detector metal ini berbahaya bagi kehamilannya, maka ia akan melewati alat tersebut dengan intensitas yang sering tanpa adanya kewaspadaan yang didasari oleh ketidakpahamannya terhadap bahaya yang dapat terjadi karena alat tersebut. Maka dari itu dalam hal ini, untuk mencegah ibu hamil dan janin yang terkandung terkena hazard radiasi, maka yang perlu dilakukan adalah dengan meningkatan pengetahuan dan pemahaman ibu hamil itu sendiri.

Namun dengan penjelasan yang sudah dijabarkan ini, bukan berarti ibu yang sedang mengandung tidak boleh menggunakan telepon genggam karena menjadi salah satu benda yang juga dapat memancarkan radiasi. Hal ini dikarenakan pancaran radiasi sendiri dapat mengenai kita meski kita tidak menggunakan alat - alat yang dapat memancarkan radiasi itu sendiri. Mengapa demikian? Karena kembali mengingat bahwa radiasi berupa gelombang yang diantarkan oleh udara dan dapat menempel pada manusia. Sesuatu yang dihantar oleh udara artinya dalam partikel udara itu sendiri sudah terkandung radiasi dari berbagai alat yang digunakan, meski kita tidak menggunakannya secara langsung.

Namun dengan demikian bukan berarti pula ibu hamil harus menghentikan semua aktivitas dirinya sendiri dan orang disekitarnya dalam menggunakan alat yang mengandung radiasi karena takut terkena hazard radiasi dalam masa kehamilannya, atau justru mengurung diri di dalam rumah karena takut terpapar radiasi yang ada pada udara. Kekhawatiran seperti itu tidak dirasa perlu karena untuk mencapai hazard itu sendiri, paparan radiasi harus dalam jumlah 
yang besar dan intensitas yang tinggi. Artinya dengan paparan yang rendah dan intensitas yang juga rendah, radiasi tidak akan mengancam kesehatan ibu hamil dan perkembangan janin.

Kembali lagi mengenai pencegahan hazard radiasi pada ibu hamil yang paling mudah adalah dengan menambah pengetahuan dan pemahaman ibu hamil itu sendiri. Karena yang bertanggung jawab terhadap kesehatan kehamilan tersebut juga adalah ibu hamil itu sendiri. Maka penting bagi ibu hamil untuk memiliki pengetahuan yang lengkap dan tepat seputar kehamilan. Setelah memiliki pengetahuan dan pemahaman tersebut, langkah selanjutnya yang dapat dilakukan adalah dengan menerapkan pengetahuan tersebut dalam aktivitas sehari - hari seperti yang juga sudah disampaikan dan dijabarkan, seperti tidak terlalu sering menggunakan telepon genggam, tidak berada di dekat alat yang memaparkan radiasi dalam jangka waktu yang lama, tidak mengkonsumsi makanan yang mengandung radiasi, tidak berobat atau melakukan pemeriksaan yang harus menggunakan alat - alat dengan radiasi, serta berbagai hal lainnya. Namun dari semua itu, kembali lagi ditegaskan bahwa yang terpenting adalah ilmu yang dimiliki oleh ibu hamil itu sendiri, agar bisa melakukan pencegahan dan terhindar dari hazard radiasi selama masa kehamilannya agar dapat mencapai kehamilan yang sehat dan perkembangan janin yang maksimal.

\section{Penutup}

Setelah pemeparan mengenai berbagai hal seputar apa itu hazard apa itu radiasi dan apa bahaya dari radiasi bagi ibu hamil dan janinnya, maka dari semua hal tersebut juga diberikan solusi yang tepat bagi ibu hamil untuk melakukan pencegahan dari hazard radiasi selama masa kehamilannya. Meski banyak hal yang memang harus lebih diperhatikan selama masa kehamilan, namun apabila ibu hamil memiliki pengetahuan dan pemahaman yang luas dan tepat seputar kehamilan, maka hal - hal tersebut menjadi mudah untuk dijalani. Maka dari itu dapat dikatakan bahwa hal yang terpenting dalam pencegahan hazard radiasi yang merupakan salah satu hal yang harus dihindari oleh ibu hamil ini adalah dengan memiliki pengetahuan seputar kehamilan dan pemahaman seputar bahaya radiasi bagi kehamilan itu sendiri. Apabila ibu hamil sudah memiliki pengetahuan dan pemahaman yang memadai, maka akan kecil kemungkinan ibu hamil dan janinnya terkena hazard radiasi. 


\section{Daftar Pustaka}

Afrianto, R. (2017). BAB II TINJAUAN PUSTAKA. Retrieved Oktober 1, 2020, from Repository.unimus.ac.id: file://C:/Users/Toshiba/AppData/Local/Temp/digital_124028-S-5613Analisis\%20resiko-Literatur.pdf

Alatas, Z. (n.d.). Efek Teratogenik Radiasi Pengion. Iptek Ilmiah Populer , 133 - 142.

Chandra, V., Dorsey, C., Reed, A. B., Shaw, P., Banghart, D., \& Zhou, W. (2013). Monitoring of fetal radiation exposure during pregnancy. Journal of Vascular Surgery, 710 - 711.

Hayati, K., \& Zuliati, R. (2011). TINGKAT PENGETAHUAN IBU HAMIL TENTANGEFEK RADIASI SINAR-XDI BIDANG KEDOKTERAN GIGIPADA SAAT KEHAMILAN(Studi Dilakukan Di Praktek Bidan Swasta Desa Suka DamaiKecamatan Lueng BataBanda Aceh). Cajradonya Dent J , 91 - 97.

Malecachi, R., \& Tjakraatmadja, R. (2018). Pencegahan Efek Radiasi pada Pencitraan Radiologi. CDK-266/vol.45 no.7 th.2018, 537 - 538.

Prriyanikka. (2016). Pengetahuan Mahasiswa KepaniteraanKlinik Tentang Bahaya RadiasiKedokteran Gigi Terhadap Wanita HamilTrimester Satu di RSGM FKG USU. Retrieved Oktober 2020, from Universitas Sumatra Utara: http://repositori.usu.ac.id/bitstream/handle/123456789/19171/110600155.pdf?sequence=1\&isAll owed $=\mathrm{y}$

Shaw, P., Duncan, A., Vouyouka, A., \& Ozvath, K. (2011). Radiation exposure and pregnancy. Journal of Vascular Surgery, 298 - 318.

Simamora, R. H. (2019). Pengaruh Penyuluhan Identifikasi Pasien dengan Menggunakan Media Audiovisual terhadap Pengetahuan Pasien Rawat Inap. Jurnal Keperawatan Silampari, 3(1), 342-351.

Simamora, R. H. (2020). Learning of Patient Identification in Patient Safety Programs Through Clinical Preceptor Models. Medico Legal Update, 20(3), 553-556.

Stein, S. G., Liu, B., Hahn, P. F., \& Lee, S. I. (2011). Body CT During Pregnancy: Utilization Trends, Examination Indications, and Fetal Radiation Doses. American Journal of Roentgenology, 146 - 151.

Uzoigwe, C. E., \& Middelton, R. G. (2012). Occupational radiation exposure and pregnancy in orthopaedics. The Journal of Bone and Joint Surgery, British Volume , 23 - 27. 
Woroprobosari, N. R. (2016). Efek Stokastik Radiasi Sinar-X Dental pada Ibu Hamil dan Janin. ODONTO Dental journal , 60 - 62. 